At $£ 34.95$ this is not an easily affordable book but it deserves to be widely read and used as a basis for information and discussion.

PROFESSOR T E OPPE Emeritus Professor of Paediatrics

\section{Perilous knowledge}

\section{Tom Wilkie, 195 pages, London, 1993, Faber and Faber, \$22.95, $£ 14.99$}

Perilous Knowledge is perfectly timed. Tom Wilkie's balanced discussion of the social and ethical implications of the human genome project will be welcomed by all those who are concerned by reports of gene therapy and 'gay genes'.

The book is divided into two sections. The first covers the history of molecular biology and describes how scientists have progressed from Darwin's complete ignorance of genetic material to our present-day sophistication. The second section considers the implications of the human genome project, taking a historical point of view. Wilkie wisely avoids wild speculation about future revolutions and instead examines how our limited genetic knowledge has been used and abused in the past.

Chapters 2-4 provide an introduction to molecular biology and its history. Despite its rather hyperbolic style, the text reads well and carries the flavour of the subject. Unfortunately, Wilkie's vow to avoid jargon and his seeming dislike for diagrammatic illustration will leave the uninitiated only superficially informed. We learn about the discovery of the structure and function of DNA. The concepts of genes and protein synthesis are presented with a description of some of the most closely studied single gene diseases.

The human genome is compared to a public library, each of the 46 bays representing a chromosome. The challenge of gene mapping and genome sequencing is to locate and read all the 50,000+ meaningful volumes (the genes) in the midst of the apparent gibberish which constitutes more than 90 per cent of the library.

Some of the technical advances which underpin the genome project and the associated biotechnology industry are mentioned in a chapter that attempts to explain recombinant
DNA technology, bacterial and viral genetics, gene splicing and more. The history of molecular biology is then rounded off with a fascinating analysis of the origins and emphases of the European and American genome projects.

The second half of the book is a ramble through the potential ethical confusion which threatens to engulf a scientifically naive society. The thrust of much of the commentary is that the new knowledge will be abused, not out of malice, but out of ignorance and hysteria.

Wilkie worries that only the rich will benefit from the new knowledge and that the poor will become a genetic underclass. Darwin told us that Man is born unequal, allowing natural selection to mould us. Galton's nineteenth century eugenics sought to replace natural selection with a programme of selective breeding. Wilkie presents a modern world where genetic screening and selective termination will permit the creation of designer children.

When the future of reproduction is so cool and logical the temptation is to think of our humanity as nothing more than a biological computer programme. James Rachels is quoted as decrying conventional morality as 'speciesist' because $H$ sapiens and other animals are no longer in different moral categories. Here, surely, is the ultimate in the humbling of Man, our moral worth is nothing more than the richness and complexity of our programme.

DAMIAN C CROWTHER 22 Hengrove Close, Barton, Headington, Oxford, OX3 $9 L N$

\section{Pro-life? The Irish question}

Michael Solomons, 86 pages, Dublin, Ireland, 1992, Lilliput Press, $£ 3.95$ (Irish punts)

The title of this book is a superb choice. The question Pro-life? is deeply provocative and philosophical in its implications. Michael Solomons scrutinises what 'pro-life' means in the Republic of Ireland and does this from a position of one who has lived in Ireland all of his life. Born in Dublin in 1919, Solomons was an obstetrician-gynaecologist until his retirement in 1988 . The book was written against the background of acrimonious Irish debate about abortion which has gone on virtually uninterrupted since 1981 . This debate was intensified in 1992 when a 14-year-old rape victim was served a High Court injunction, initiated by the Attorney General, preventing her from legally travelling to England for an abortion. A society which goes to such lengths to prevent a rape victim from having an abortion might be explained by its history and Solomons's study provides a great deal of that history. In Pro-life? The Irish Question, Solomons tells the complex story of Irish policies on contraception and abortion over the last seventy years. Ireland's laws governing matters of reproduction have resulted from the interaction of religious, cultural, legal and medical institutions which have traditionally reinforced a pro-natalist viewpoint, reiterating women's 'proper moral roles' as mother and reproducer. The national hegemony of the Roman Catholic Church in the republic has provided the main institutional support for religious orthodoxy on questions of reproduction.

Abortion in Ireland has been legally prohibited under the British Offences Against the Person Act of 1861. In rare cases such as ectopic pregnancy, therapeutic abortions have been quietly tolerated in Ireland under the traditional principle of double effect. In September 1983, after two years of acrimonious public debate on abortion, a national referendum passed the Eighth Amendment to the Irish Constitution which reads: 'The State acknowledges the right to life of the unborn and, with due regard to the equal right to life of the mother, guarantees in its laws to protect, and as far as practicable, by its laws, to defend and vindicate that right.'

The ambiguities of meaning in this amendment were noted from its first publication. In debating the amendment, many voices had argued that a constitution is not a suitable mechanism for determining abortion policies within a country. Events in Ireland since 1983 have confirmed that judgement. The Irish legal ban on abortion in no way reflects the reality of abortion choice by Irish women. Since abortion became legal in Britain in 1969 , it is estimated that 5,000 women each year travel to Britain for abortions. However, this figure is almost certainly an underestimate. For many Irish women who choose abortions in England do not use an Irish address for fear of identification 
or possibly even criminal prosecution under present Irish law.

The label 'pro-life' is often used by opponents of abortion, and certain forms of contraception, as a synopsis phrase for what is often an unarticulated and complex moral and political position. This moral/political view includes: beliefs about sexual behaviour and personal choice; the influence of religious belief in determining sexual morality and, finally, an appraisal of ethical pluralism in a democracy. In international debates on the term, 'pro-life', is most often set in opposition to 'pro-choice' where adherents of choice argue for legal provisions to enable women to make their own choices about reproduction. Solomons's book is written for a broad and non-specialist readership who care to re-think their understanding of 'pro-life'. Readers are not given philosophical arguments nor analyses about 'pro-life' positions. Rather we are given a careful empirical case study of one country's 'pro-life' policies and the inspirations and ideological bases for those policies over seven decades. Using this case-study method, the book encourages critical and often agonising reflection on the meaning of 'pro-life' discourse. The reader is left with troubling questions about the consequences for family life, women's autonomy and political tolerance when the language of 'pro-life' is coopted to mean predominantly respect for fetal human life.

The vigorous activities of Irish women's groups in Ireland have been increasingly vocal in urging a legal repudiation of a traditional 'pro-life' stance which denigrates women's liberty while exalting her maternal potential. At this point in time, Ireland is waiting for legislation on abortion following Attorney General $v$ : $X$ and Others, a Supreme Court judgement given in February of 1992 which states that abortion should be permitted within the state under limited circumstances including the real probability of a woman committing suicide because of a pregnancy. The govern- ڤ ment's promised legislation on abor- tion will need to be guided by the wisdom of Solomon and legislators could benefit from a sobering read of Solomons's accessible cultural study about reproductive politics in Ireland.

DOLORES DOOLEY Department of Philosophy, $\vec{N}$ University College, o Cork, Ireland ف่

\section{Submitting manuscripts for publication}

Papers submitted for publication should be sent in quadruplicate to: The Editor, fournal of Medical Ethics, c/o Imperial College of Science, Technology and Medicine, 14 Prince's Gardens, London SW7 1NA. Rejected manuscripts are not returned. Papers should be in double-spaced typewriting on one side of the paper only. The preferred maximum length of papers is 3,500 words - absolute maximum $\mathbf{5 , 5 0 0}$ (including references). A total word count (including references) is requested. On a separate sheet some brief biographical details should be supplied, including the title of the author's present post, degrees and/or professional qualifications (if any), and any other relevant information.

Two copies of the journal will be sent to authors free of charge after their papers are published. Offprints of individual papers may be bought from fournal of Medical Ethics, BMA House, Tavistock Square, London WC1H 9JR.

In March 1981 the $\mathcal{F M E}$ adopted a simplified 'Vancouver style' for references: details are given in various issues, including Decembero 1990. They are also available from the editorial office. The full text of the 'Vancouver Agreement' was' published in the British Medical Fournal in 1988; volume 296; 401-405. As the 'Vancouver style' is incompatible with the long established style of references for legal articles, lawyers should use their own standard style, but try to facilitate reference by others. The journal is multidisciplinary and papers should be in clear jargonfree English, accessible to any intelligent reader. 